\title{
The $\mathrm{Na}^{+}$-translocating NADH : ubiquinone oxidoreductase of Azotobacter vinelandii negatively regulates alginate synthesis
}

\begin{abstract}
Correspondence
Cinthia Núñez

cinthia@ibt.unam.mx
\end{abstract}

Received 4 August 2008

Revised 5 October 2008

Accepted 16 October 2008

\author{
Cinthia Núñez, ${ }^{1}$ Alexander V. Bogachev, ${ }^{2}$ Gabriel Guzmán, ${ }^{1}$ Isaac Tello, ${ }^{1}$ \\ Josefina Guzmán ${ }^{1}$ and Guadalupe Espín ${ }^{1}$
}

\author{
${ }^{1}$ Departamento de Microbiología Molecular, Instituto de Biotecnología, Universidad Nacional \\ Autónoma de México, Av. Universidad 2001, Col. Chamilpa, Cuernavaca, Morelos 62210, Mexico \\ ${ }^{2}$ Department of Molecular Energetics of Microorganisms, A. N. Belozersky Institute of Physico- \\ Chemical Biology, Moscow State University, Moscow 119992, Russia
}

\begin{abstract}
Azotobacter vinelandii is a nitrogen-fixing soil bacterium that produces the exopolysaccharide alginate. In this report we describe the isolation and characterization of $A$. vinelandii strain GG4, which carries an nqrE: :Tn5 mutation resulting in alginate overproduction. The nqrE gene encodes a subunit of the $\mathrm{Na}^{+}$-translocating $\mathrm{NADH}$ : ubiquinone oxidoreductase $\left(\mathrm{Na}^{+}-\mathrm{NOR}\right)$. As expected, $\mathrm{Na}^{+}$-NQR activity was abolished in mutant GG4. When this strain was complemented with the $n q r E F$ genes this activity was restored and alginate production was reduced to wild-type levels. $\mathrm{Na}^{+}$-NQR may be the main sodium pump of $A$. vinelandii under the conditions tested $\left(\sim 2 \mathrm{mM} \mathrm{Na}^{+}\right)$since no $\mathrm{Na}^{+} / \mathrm{H}^{+}$-antiporter activity was detected. Collectively our results indicate that in $A$. vinelandii the lack of $\mathrm{Na}^{+}-\mathrm{NOR}$ activity caused the absence of a transmembrane $\mathrm{Na}^{+}$ gradient and an increase in alginate production.
\end{abstract}

\section{INTRODUCTION}

Alginates are a family of unbranched, non-repeating copolymers composed of variable amounts of $(1,4)-\beta$-Dmannuronic acid and its epimer, $\alpha$-L-guluronic acid. These biopolymers have various technological applications, e.g. as a stabilizing, thickening and gelling agent in food production or for immobilizing cells in the pharmaceutical and biotechnology industries (Rehm \& Valla, 1997; Remminghorst \& Rehm, 2006).

Azotobacter vinelandii is a nitrogen-fixing soil bacterium that produces the intracellular polymer polyhydroxybutyrate $(\mathrm{PHB})$ and excretes copious amount of alginate into the medium during vegetative growth. Alginate is also produced when this bacterium undergoes differentiation into metabolically dormant, desiccation-resistant cysts (Sadoff, 1975). The cysts are surrounded by a rigid coat consisting of two layers mainly composed of alginate, and hence a mutant unable to produce alginate fails to encyst (Campos et al., 1996; Mejía-Ruiz et al., 1997a).

In A. vinelandii all genes involved in the biosynthesis of alginate, except $\operatorname{alg} C$, are clustered in the chromosome and are headed by algD, encoding a GDP-mannose dehydrogenase, an enzyme catalysing the committed step in the biosynthesis of

Abbreviations: $\Delta \mathrm{pH}$, transmembrane difference in $\mathrm{pH} ; \mathrm{Na}^{+}-\mathrm{NOR}, \mathrm{Na}^{+}{ }_{-}$ translocating $\mathrm{NADH}$ : ubiquinone oxidoreductase; $\mathrm{NDH}, \mathrm{NADH}$ : quinone oxidoreductase; PHB, polyhydroxybutyrate. this polymer (Campos et al., 1996). Transcription of algD and $\operatorname{alg} C$ is positively controlled by the extracytoplasmic function sigma factor AlgU. algD expression is also controlled by the two-component system GacS/GacA, which regulates secondary metabolism in many Gram-negative bacteria (Castañeda et al., 2000, 2001; Gaona et al., 2004).

In A. vinelandii, as in Pseudomonas aeruginosa, AlgU is essential for alginate production and is encoded in the algUmucABCD operon (Martínez-Salazar et al., 1996; Schurr et al., 1996); MucA is an inner-membrane protein that acts as an anti-AlgU sigma factor by directly sequestering $\mathrm{Alg} U$ and inhibiting its activity. An algU mutant of $A$. vinelandii was unable to synthesize alginate. In contrast, a mucA mutation increased $\operatorname{alg} D$ and $\operatorname{alg} C$ transcription and consequently alginate production (Gaona et al., 2004; Núnez et al., 2000a).

Other mutations resulting in an increase of alginate production in $A$. vinelandii have been reported (Núñez et al., 2000b; Segura et al., 2003); a Tn5 insertion within ampD, encoding a cytosolic $N$-acetyl-anhydromuramyl-Lalanine amidase involved in the recycling of peptidoglycan fragments, increased algD transcription and alginate production. In addition a mutation within the structural gene $p h b B$, which impaired $\mathrm{PHB}$ production, increased alginate yields, presumably as a consequence of higher carbon source availability for the synthesis of alginate (Segura et al., 2003). 
$\mathrm{Na}^{+}$-translocating $\mathrm{NADH}$ : ubiquinone oxidoreductases $\left(\mathrm{Na}^{+}-\mathrm{NQR}\right)$ are redox-driven sodium pumps composed of six subunits, NqrA-F, which are encoded in the $n q r$ operon (Hayashi et al., 1995; Nakayama et al., 1998; Rich et al., 1995). This enzyme couples the exergonic oxidation of NADH with ubiquinone to the transport of $\mathrm{Na}^{+}$from the cytoplasmic to the periplasmic space (Skulachev, 1989). Thus, $\mathrm{Na}^{+}{ }_{-} \mathrm{NQR}$ diminishes the internal $\mathrm{Na}^{+}$concentration and contributes to the generation of an electrochemical $\mathrm{Na}^{+}$potential. This sodium transmembrane potential plays a significant role in the metabolism of various bacteria, in which it is involved in solute import, ATP synthesis and flagellar rotation (Skulachev, 1989). In Vibrio cholerae the sodium-motive force, which is maintained by $\mathrm{Na}^{+}-\mathrm{NQR}$, strongly influences the production of virulence factors. Loss of $\mathrm{Na}^{+}-\mathrm{NQR}$ results in altered virulence gene regulation in $V$. cholerae, but the putative link between sodium membrane energetics and virulence remains unclear (Häse \& Mekalanos, 1999). Although $\mathrm{Na}^{+}-\mathrm{NQR}-$ type enzymes have been investigated primarily in members of the genus Vibrio (Barquera et al., 2002; Bogachev et al., 2001, 2002; Duffy \& Barquera, 2006; Häse \& Barquera, 2001; Tokuda \& Unemoto, 1982) it has recently been shown that homologous nqr operons are present in a variety of bacteria, including several pathogens such as Haemophilus influenzae, Neisseria gonorrhoeae, P. aeruginosa and Chlamydia trachomatis (Dibrov et al., 2004; Häse et al., 2001).

The nqroperon is also found in A. vinelandii. In this report we describe the isolation of an $A$. vinelandii $\operatorname{Tn} 5$ mutant strain carrying an insertion within the nqrE gene, encoding a subunit of the $\mathrm{Na}^{+}-\mathrm{NQR}$ complex, that resulted in alginate overproduction.

\section{METHODS}

Microbiological procedures. Bacterial strains and plasmids are listed in Table 1. Media and growth conditions were as follows. A. vinelandii was grown at $30{ }^{\circ} \mathrm{C}$ in Burk's nitrogen-free salts supplemented with $2 \%$ sucrose (BS) or in BS medium supplemented with $15 \mathrm{mM}$ ammonium acetate (BSN) (Kennedy et al., 1986). Escherichia coli $\mathrm{DH} 5 \alpha$ was grown on Luria-Bertani (LB) medium at $37{ }^{\circ} \mathrm{C}$ (Miller, 1972). Antibiotic concentrations used for A. vinelandii and E. coli, respectively, were as follows: spectinomycin, 50 and $100 \mu \mathrm{g} \mathrm{ml}^{-1}$; gentamicin, 0.5 and $10 \mu \mathrm{g} \mathrm{ml}^{-1}$; ampicillin, $100 \mu \mathrm{g}$ $\mathrm{ml}^{-1}$ (not used for A. vinelandii).

A. vinelandii transformation was carried out as previously described (Page \& von Tigerstrom, 1978) with some modifications of the method. In brief, $A$. vinelandii was cultured twice on solid competence medium (CM; BS medium lacking Fe and Mo) followed by a subculture into $50 \mathrm{ml}$ liquid CM. Cells were harvested and resuspended in $0.5 \mathrm{ml} \mathrm{CM}$ containing $16 \mathrm{mM} \mathrm{MgSO}_{4} ; 100 \mu \mathrm{l}$ of this suspension was transformed with $5 \mu \mathrm{g}$ plasmid DNA. This mix was spread over $\mathrm{CM}$ plates and incubated at $30{ }^{\circ} \mathrm{C}$ for $24 \mathrm{~h}$. Cells were then recovered and resuspended in $1 \mathrm{ml} \mathrm{MgSO}_{4}$. A. vinelandii transformants were isolated on BS plates containing the corresponding antibiotic.

Alginate production was determined as previously described (MejíaRuiz et al., 1997b).
Transposon mutagenesis. Random transposon mutagenesis of $A$. vinelandii strain AEIV was carried out using the minitransposon mTn5SSgusA40 (Wilson et al., 1995). Strain AEIV was cultured in $50 \mathrm{ml}$ BS medium for $48 \mathrm{~h}$ and then cells were harvested and resuspended in $1 \mathrm{ml} 10 \mathrm{mM} \mathrm{MgSO}_{4}$. E. coli strain S17-1 $\lambda$-pir carrying the mini Tn5SSgusA40 transposon (Wilson et al., 1995) was grown for $24 \mathrm{~h}$ in $5 \mathrm{ml} \mathrm{LB}$ medium amended with spectinomycin. The cells were then washed and resuspended in $1 \mathrm{ml}$ fresh LB medium. Aliquots $(100 \mu \mathrm{l}$ each) of the E. coli and A. vinelandii cell suspensions were mixed and spread over the surface of a BS plate containing $30 \%(\mathrm{v} / \mathrm{v})$ LB medium and $0.2 \%$ glucose. The cells were incubated for $24 \mathrm{~h}$ at $30{ }^{\circ} \mathrm{C}$ to allow conjugation. The resultant $A$. vinelandii transconjugants were isolated on BS plates containing spectinomycin. Since BS medium lacks a fixed N source, E. coli cells were unable to grow.

Nucleic acid procedures. Genomic DNA was extracted with the MasterPure Complete DNA \& RNA Purification kit (Epicentre Technologies). Plasmid DNA and PCR products were purified using the Roche High Pure plasmid isolation kit and the rapid PCR purification system (Marligen Biosciences), respectively. DNA cloning and other manipulations were carried out according to the methods outlined in Sambrook et al. (1989). Probes for Southern blot analysis were $\left[\alpha_{-}{ }^{32} \mathrm{P}\right] \mathrm{dCTP}$ labelled with the Rediprime II kit from GE Healthcare. The $A$. vinelandii genome sequence is available via the Integrated Microbial Genome Sequence web page (http://img.jgi. doe.gov/cgi-bin/pub/main.cgi) and this sequence was used for designing the oligonucleotides used for PCR amplifications. Taq DNA polymerase was used for all PCR amplifications.

Cloning the transposon insertion. Transposon mTn5SSgus $A 40$ lacks sites for the PstI endonuclease. Chromosomal DNA from A. vinelandii GG4 was restricted with this enzyme. The PstI chromosomal fragment interrupted by the transposon was ligated into pBluescript $\mathrm{KS}^{+}$(Table 1) and was transformed into E. coli DH5 $\alpha$. A spectinomycin-resistant transformant harbouring plasmid pGGCN4 was isolated (Table 1). This plasmid was used to determine the sequence of the interrupted locus in the GG4 mutant. DNA sequencing was performed as described, using oligonucleotides Tn5I ( $5^{\prime}$-GGC CAG ATC TGA TCA AGA G-3') and Tn5O (5'-GGC CGC ACT TGT GTA TAA G-3') (Núñez et al., 2000b). Sequence analysis revealed that the Tn5 insertion in A. vinelandii GG4 lies within a 930 bp PstI fragment (Fig. 1a).

Construction of mutant ATCN4. A. vinelandii ATCC 9046 was transformed with plasmid pGGCN4, carrying the nqrE::Tn5 insertion (Fig. 1a). To ensure that incorporation of the disrupted $n q r E$ coding sequence into the chromosome occurred via a double recombinant event, pGGCN4 was linearized with PstI prior to transformation. Transformants were selected on BS plates amended with spectinomycin. The replacement of the wild-type $n q r E$ gene by the nqrE: :Tn5 insertion was confirmed by Southern blotting (data not shown), and the resultant strain was named ATCN4.

Construction of plasmid pCN41. The $n q r E$ and $n q r F$ genes were amplified by PCR using oligonucleotides nqrEFF ( $5^{\prime}$-GCA AAC TGT TCG GCT TCA CC- $3^{\prime}$ ) and nqrEFR ( $5^{\prime}$-ATG GCG GGC TTC AGC AGT G-3') and an annealing temperature of $58{ }^{\circ} \mathrm{C}$; genomic DNA from strain UW136 (Kennedy et al., 1986) was used as the template. The nqrEF gene product was ligated into pMOSblue vector using the pMOSblue blunt-ended cloning kit (GE Healthcare), and the resultant plasmid was named pCN40. We have previously shown that genes located downstream of the $\mathrm{Gm}^{\mathrm{r}}$ cassette from plasmid pBSL141 (Alexeyev et al., 1995) are transcribed from the promoter directing transcription of the gentamicin-resistance gene (Núñez et al., 2000a). A BamHI fragment containing this cassette was ligated into the 
Table 1. Bacterial strains and plasmids used in this work

\begin{tabular}{|c|c|c|}
\hline Strain or plasmid & Relevant characteristics & Source of reference \\
\hline \multicolumn{3}{|l|}{ A. vinelandii } \\
\hline AEIV & Wild-type, mucoid & S. Valla* \\
\hline $\mathrm{CN} 14$ & GG4 derivative carrying pCN41 cointegrated in the chromosome & This work \\
\hline ATCC 9046 & Highly mucoid & ATCC \\
\hline ATCN4 & ATCC 9046 derivative carrying the $n q r E:: \operatorname{Tn} 5$ mutation & This work \\
\hline \multicolumn{3}{|l|}{ E. coli } \\
\hline DH5 $\alpha$ & supE44 $\Delta$ lacU169 hsdR17 recA1 endA gyrA96 thi-1 relA1 & Sambrook et al. (1989) \\
\hline GR70N & $\mathrm{F}^{-}$thi rpsL gal; $\mathrm{Str}^{\mathrm{R}}$ & Green et al. (1984) \\
\hline \multicolumn{3}{|l|}{ Plasmids } \\
\hline pBluescript $\mathrm{KS}^{+}$ & Used for subcloning DNA; $\mathrm{Ap}^{\mathrm{r}}$ & Stratagene \\
\hline pMOSblue & Used for subcloning PCR products; $A p^{r}$ & Amersham \\
\hline
\end{tabular}

${ }^{\star}$ S. Valla, Norwegian University of Science and Technology, N-7491 Trondheim.

polylinker of pCN40 to direct transcription of the nqrEF genes. The resultant plasmid was named pCN41 (Fig. 1a).

Genetic complementation of mutants GG4 and ATCN4. Plasmid pCN41, carrying the nqrEF genes and unable to replicate in $A$. vinelandii, was used to complement nqrE: $: \operatorname{Tn} 5$ mutants by its cointegration into the chromosome, as has been reported before (Núñez et al., 1999; Segura \& Espin, 1998). Competent A. vinelandii GG4 and ATCN4 cells were transformed with $5 \mu$ g supercoiled pCN41 (Fig. 1b). Transformants in which pCN41 was co-integrated into the chromosome were isolated on BS plates containing gentamicin and spectinomycin, and co-integration was confirmed by Southern blotting (Fig. 1c). In all five candidates tested, co-integration of plasmid pCN41 had occurred donwnstream of the nqrE::Tn5 insertion. This event was expected, as the corresponding Tn5 downstream region in pCN41 is twice as long as the upstream one. One such candidate was chosen for further analysis and the resultant GG4 and ATCN4 derivative strains were named CN14 and NL17, respectively.

Preparation of sub-bacterial particles and determination of NADH dehydrogenase activity and $\Delta \mathbf{p H}$ formation. $E$. coli and $A$. vinelandii cells were grown in LB and BSN media respectively, harvested by centrifugation $(10000 \mathrm{~g}, 10 \mathrm{~min})$ and washed twice with medium $1\left(250 \mathrm{mM} \mathrm{KCl}, 10 \mathrm{mM}\right.$ Tris/ $\mathrm{HCl}$ and $5 \mathrm{mM} \mathrm{MgSO}_{4}$, $\mathrm{pH}$ 8.0). The cell pellet was subsequently suspended in medium 2 (20 mM HEPES-Tris, $5 \mathrm{mM} \mathrm{MgSO}_{4}, 100 \mathrm{mM} \mathrm{KCl}, \mathrm{pH}$ 8.0) and the suspension was passed through a French press $(110400 \mathrm{kPa})$. Undamaged cells and cell debris were removed by centrifugation at $22500 \mathrm{~g}(10 \mathrm{~min})$ and the supernatant was further centrifuged at $180000 \mathrm{~g}$ for $60 \mathrm{~min}$. The membrane pellet was suspended in medium 2 at $20-30 \mathrm{mg}$ protein $\mathrm{ml}^{-1}$. As shown previously (Bertsova \& Bogachev, 2002) this procedure produces membrane vesicles with a mixed orientation with a ratio from $3: 1$ to $4: 1$ of 'inside out' to 'right-side out' particles. Since in all experiments we used a substrate (NADH) non-permeable through bacterial membranes, only 'inside out' oriented vesicles were active in our study. These vesicles have low $\mathrm{H}^{+}$permeability and are suitable for investigation of $\Delta \mathrm{pH}$ formation (Bertsova et al., 1998).
The rates of NADH and dNADH oxidation by sub-bacterial particles were measured in medium 2 at $30{ }^{\circ} \mathrm{C}$ using a Hitachi-557 spectrophotometer as described previously (Bertsova \& Bogachev, 2002).

$\Delta \mathrm{pH}$ formation by sub-bacterial particles was monitored using acridine orange fluorescence quenching (MPF-4 fluorimeter: excitation, $492 \mathrm{~nm}$; emission, $530 \mathrm{~nm}$ ) (Bertsova et al., 1998). The incubation mixture contained medium $2,4 \mu \mathrm{M}$ acridine orange and sub-bacterial particles (40-60 $\mu \mathrm{g}$ protein $\mathrm{ml}^{-1}$ ). A $2 \mathrm{ml}$ sample was incubated for $5 \mathrm{~min}$ and respiration was initiated by adding $2 \mathrm{mM}$ $\mathrm{NADH}$ (Tris salt).

\section{RESULTS}

\section{Isolation of the alginate-overproducing mutant GG4}

A. vinelandii strain AEIV produces low levels of alginate, and therefore shows a slightly mucoid phenotype on BS plates (Campos et al., 1996). Random Tn5 mutagenesis of this strain was conducted as described in Methods and a total of 4200 isolates $\left(\mathrm{Sp}^{\mathrm{r}}\right)$ were obtained. This bank of mutants was screened for derivatives showing a highly mucoid colony morphology. Strain GG4, which had a stable alginate-overproducing phenotype, was chosen for further analysis. Its specific alginate production was 60 -fold higher than that of the parental strain AEIV after $48 \mathrm{~h}$ of growth on solid BS medium [3200 vs $52 \mu \mathrm{g}$ alginate $(\mathrm{mg}$ protein $)^{-1}$; Table 2].

\section{$\mathrm{Na}^{+}-\mathrm{NQR}$ negatively regulates alginate synthesis}

The PstI fragment carrying the site of transposition in mutant GG4 was subcloned and the sequence of the 
(a)

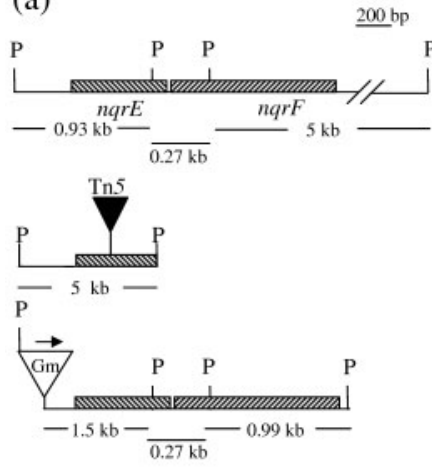

AEIV

wild-type strain

pGGCN4

pCN41

(c)

(b)
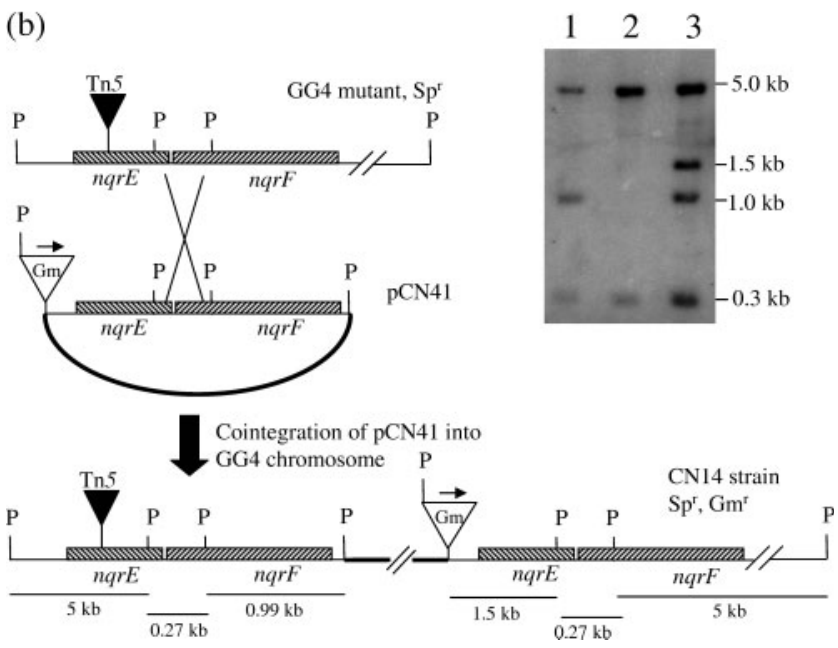

Fig. 1. (a) Physical map of the nqrEF locus in A. vinelandii and of plasmids constructed in this work. (b) Schematic representation of the co-integration of plasmid pCN41 into the chromosome of GG4 in order to complement this mutant. (c) Southern blot hybridization of total genomic DNA digested with Pstl, with nqrEF PCR product as the probe. Lanes: 1, AEIV; 2, GG4; 3, CN14. The hybridization pattern of strain $\mathrm{CN} 14$ is consistent with that of the predicted pCN41 co-integration event downstream of the nqrE::Tn5 insertion as depicted in (b). Arrows indicate the direction of transcription. Antibiotic-resistance cassettes and Tn5 are not shown to scale. P, Pstl.

flanking Tn5 regions was determined, as described in Methods. The sequence obtained revealed that the Tn5 insertion in mutant GG4 is located within the nqrE gene, which forms part of the $\mathrm{Na}^{+}-\mathrm{NQR}$ gene cluster in $A$. vinelandii (nqrA-F), encoding the $\mathrm{Na}^{+}-\mathrm{NQR}$ complex (GenBank accession numbers from ZP_00416255 to ZP_00416260). The transposon disrupted codon 94 (nucleotide 281) of the predicted NqrE protein and was inserted in the orientation opposite to that of nqrE transcription. Genetic complementation of mutant GG4 was conducted by co-integration into the chromosome of wild-type copies of both nqrE and $n q r F$ genes transcribed from the promoter of the $\mathrm{Gm}^{\mathrm{r}}$ cassette of plasmid pCN41
Table 2. Alginate production by $A$. vinelandii wild-type strains and $n q r E:: \operatorname{Tn} 5$ derivative mutants

\begin{tabular}{|lc|}
\hline Strain & $\begin{array}{c}\text { Alginate production } \\
{\left[\boldsymbol{\mu g}(\mathbf{m g} \text { protein })^{-1}\right]^{\star}}\end{array}$ \\
\hline AEIV & $52 \pm 8$ \\
GG4 $(n q r E:: \operatorname{Tn} 5)$ & $3200 \pm 203$ \\
CN14 $\left(n q r E F^{+}\right)$ & $64 \pm 12$ \\
ATCC 9046 & $800 \pm 84$ \\
ATCN4 $(n q r E:: \operatorname{Tn} 5)$ & $3400 \pm 422$ \\
NL17 $\left(n q r E F^{+}\right)$ & $1406 \pm 58$ \\
\hline
\end{tabular}

*Alginate was determined in cells grown for $48 \mathrm{~h}$ on solid BS medium. Data shown are the means $\pm S D$ from three replicate cultures.

(Fig. 1a). As shown in Table 2, the resultant strain CN14 exhibited low alginate levels similar to those observed for wild-type strain AEIV.

\section{Alginate production in the background of strain ATCC 9046}

ATCC 9046 is a highly mucoid strain of A. vinelandii, producing approximately 10 times more alginate than strain AEIV (Table 2). Strain ATCC 9046 was transformed with plasmid pGGCN4, carrying the $n q r E:: \operatorname{Tn} 5$ insertion, and mutant ATCN4 was isolated as described in Methods. Elimination of the $\mathrm{Na}^{+}-\mathrm{NQR}$ complex in the background of strain ATCC 9046 increased alginate production to levels similar to those observed in mutant GG4 (Table 2). Furthermore, genetic complementation of mutant ATCN4 with the $n q r E F$ genes diminished alginate production to a level slightly higher than that of the ATCC 9046 wild-type strain. These results indicate that the negative effect of the $\mathrm{Na}^{+}$-NQR complex on the biosynthesis of alginate is not strain specific.

\section{$\mathrm{Na}^{+}-\mathrm{NQR}$ activity in $\mathrm{A}$. vinelandii}

A BLAST search of the draft sequence of the A. vinelandii genome (http://img.jgi.doe.gov/cgi-bin/pub/main.cgi) revealed that as well as the nqr genes, this bacterium contains genes for two additional respiratory-chain-linked $\mathrm{NADH}$ : quinone oxidoreductases (NDH): a gene encoding an NDH-2 type (GenBank accession number ZP_00415587), and 13 genes encoding the subunits of NDH-1 (GenBank accession numbers from ZP_00417514 to ZP_00417526). NDH-1- and NDH-2-type enzymes have been shown to function in $A$. vinelandii (Bertsova et al., 2001), whereas the activity of the $\mathrm{Na}^{+}$-NQR-type enzyme had not been previously detected.

The different types of NDH have different substrate specificity with respect to pyridine dinucleotides as well as different sensitivities to inhibitors. The NDH-1- and NQR-type enzymes oxidize NADH as well as its analogue 
dNADH (Bertsova \& Bogachev, 2004); however, NDH-1 enzyme activity is specifically inhibited by rolliniastatin (Degli Esposti et al., 1994). NDH-2-type enzymes generally oxidize only NADH, but not dNADH (Bertsova \& Bogachev, 2004). To determine whether the $\mathrm{Na}^{+}-\mathrm{NQR}$ was functional in A. vinelandii, either NADH- or dNADHoxidase activities of strains AEIV and GG4 were studied. Sub-bacterial particles from A. vinelandii AEIV oxidized either NADH or dNADH with rates of 2.1 and $0.9 \mu \mathrm{mol}$ $\min ^{-1}$ (mg protein $)^{-1}$, respectively. As can be seen from Fig. 2, dNADH oxidase activity of strain AEIV was only partially sensitive to rolliniastatin. Sub-bacterial particles from A. vinelandii GG4 (nqrE::Tn5) also oxidized NADH as well as dNADH [with respective rates of 2.4 and $0.5 \mu \mathrm{mol} \mathrm{min}{ }^{-1}$ ( $\mathrm{mg}$ protein $\left.)^{-1}\right]$. However, in contrast to the wild-type strain AEIV or the complemented strain $\mathrm{CN} 14$, the dNADH oxidase activity of $A$. vinelandii GG4 was completely inhibited by rolliniastatin (Fig. 2), and by low concentrations of piericidin A (data not shown). It has also been shown that rolliniastatin-resistant NADH oxidase activity is specifically stimulated by $\mathrm{Na}^{+}$(Fadeeva et al., 2008). These data imply that there are two different enzymes capable of dNADH oxidation (NDH- 1 and $\mathrm{Na}^{+}$$\mathrm{NQR}$ ) in wild-type $A$. vinelandii, while the $\mathrm{Na}^{+}-\mathrm{NQR}$ enzyme is absent in the GG4 mutant. Taken together these results demonstrate that a $\mathrm{Na}^{+}$-NQR-type enzyme, encoded by the nqr gene cluster, operates in the respiratory chain of $A$. vinelandii.

\section{$\mathrm{Na}^{+} / \mathrm{H}^{+}$-antiporter activity is not detectable in A. vinelandii at low $\mathrm{Na}^{+}$concentrations}

In the majority of micro-organisms, the transmembrane $\mathrm{Na}^{+}$gradient is formed by secondary processes such as $\mathrm{Na}^{+} / \mathrm{H}^{+}$-antiport (Padan et al., 2001). Therefore, we

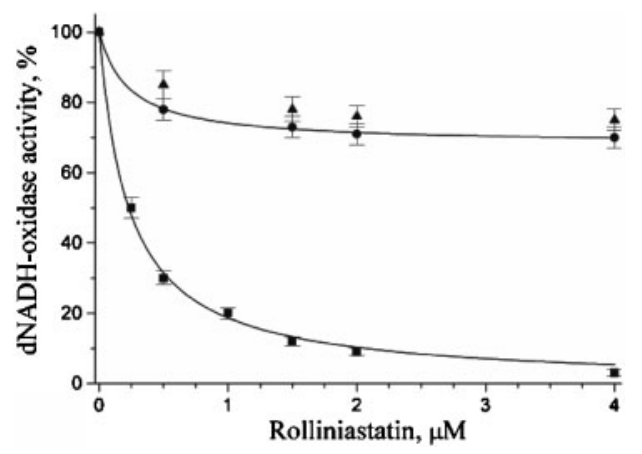

Fig. 2. Effect of rolliniastatin on the dNADH oxidase activities of sub-bacterial particles from A. vinelandii AEIV (0), GG4 (ם) and $\mathrm{CN} 14$ (A). Activities were measured in medium containing $20 \mathrm{mM}$ HEPES-Tris, $5 \mathrm{mM} \mathrm{MgSO} 4,100 \mathrm{mM} \mathrm{KCl}$ and $20 \mathrm{mM} \mathrm{NaCl}$, $\mathrm{pH}$ 8.0. The activity without the inhibitor for sub-bacterial particles from strains AEIV, GG4 and CN14 was $0.9,0.5$ and $0.8 \mu \mathrm{mol}$ dNADH oxidized $\min ^{-1}$ (mg protein) $)^{-1}$, respectively. Error bars represent standard deviation for triplicate experiments. measured the $\mathrm{Na}^{+} / \mathrm{H}^{+}$-antiporter activity in A. vinelandii by comparing the properties of $A$. vinelandii sub-bacterial particles to those of E. coli, which expresses $\mathrm{Na}^{+} / \mathrm{H}^{+}$antiporters. As can be seen in Fig. 3(a), NADH oxidation by sub-bacterial particles of $E$. coli in sodium-free medium resulted in $\Delta \mathrm{pH}$ formation. Subsequent $\mathrm{NaCl}$ addition led to a transient decrease in $\Delta \mathrm{pH}$ due to $\mathrm{Na}^{+} / \mathrm{H}^{+}$-antiporter activity (Dibrov et al., 2005). In contrast, addition of $\mathrm{NaCl}$ to respiring sub-bacterial particles from wild-type $A$. vinelandii AEIV did not change the $\Delta \mathrm{pH}$ formed (Fig. $3 \mathrm{~b})$. The same results were also obtained using subbacterial particles from the $A$. vinelandii GG4 mutant (Fig. $3 c)$. These data indicate that, under the condition tested $\left(\sim 2 \mathrm{mM} \mathrm{Na}^{+}\right), \mathrm{Na}^{+} / \mathrm{H}^{+}$-antiporter activity is very low or absent in $A$. vinelandii and suggest that the $\mathrm{Na}^{+}-\mathrm{NQR}$ complex is the main $\mathrm{Na}^{+}$pump necessary to maintain a transmembrane $\mathrm{Na}^{+}$gradient on the cytoplasmic membrane of this bacterium. This result implies that the absence of a transmembrane $\mathrm{Na}^{+}$gradient in the nqrE::Tn5 mutant might increase alginate production.

\section{Effect of osmolarity on alginate synthesis}

To assess the effect of exogenous $\mathrm{Na}^{+}$upon alginate production A. vinelandii wild-type strains AEIV and ATCC 9046, and their nqrE: : $\operatorname{Tn} 5$ derivative mutants, were grown on BS plates amended with increasing concentrations of $\mathrm{NaCl}$. Alginate production was measured on cultures grown for $72 \mathrm{~h}$. As shown in Table 3, exogenous $\mathrm{Na}^{+}$ had a negative effect on alginate biosynthesis; a complete impairment of alginate synthesis was achieved at $150 \mathrm{mM}$ $\mathrm{NaCl}$ for A. vinelandii wild-type strains AEIV and ATCC 9046, which exhibited alginate production values of 2.4 and $2.9 \mu \mathrm{g}(\mathrm{mg} \text { protein })^{-1}$, respectively. These values are similar to those obtained for alginate-minus mutants of A. vinelandii (Mejía-Ruiz et al., 1997b). Alginate production in mutants GG4 and ATCN4 was also inhibited in the presence of $50 \mathrm{mM} \mathrm{NaCl}$; however, it was not totally impaired at $150 \mathrm{mM} \mathrm{NaCl}$. The GG4 complemented strain CN14 regained the total inhibition of alginate synthesis in the presence of $150 \mathrm{mM} \mathrm{NaCl}$.

In order to test whether the negative effect of exogenous $\mathrm{NaCl}$ on alginate production was due to the presence of $\mathrm{Na}^{+}$or was a reflection of changes in medium osmolarity we conducted the same experiment using $\mathrm{KCl}$. Alginate production was inhibited in the presence of this salt in a manner similar to that observed in the presence of $\mathrm{NaCl}$ (data not shown). This result indicates that alginate production is negatively affected by an increase in medium osmolarity rather than by the presence of high concentrations of exogenous $\mathrm{Na}^{+}$.

\section{DISCUSSION}

Prior to this work, we reported that either a total blockade in PHB synthesis, a defect in the cell wall or mutations disrupting the genes mucABCD resulted in high levels of 


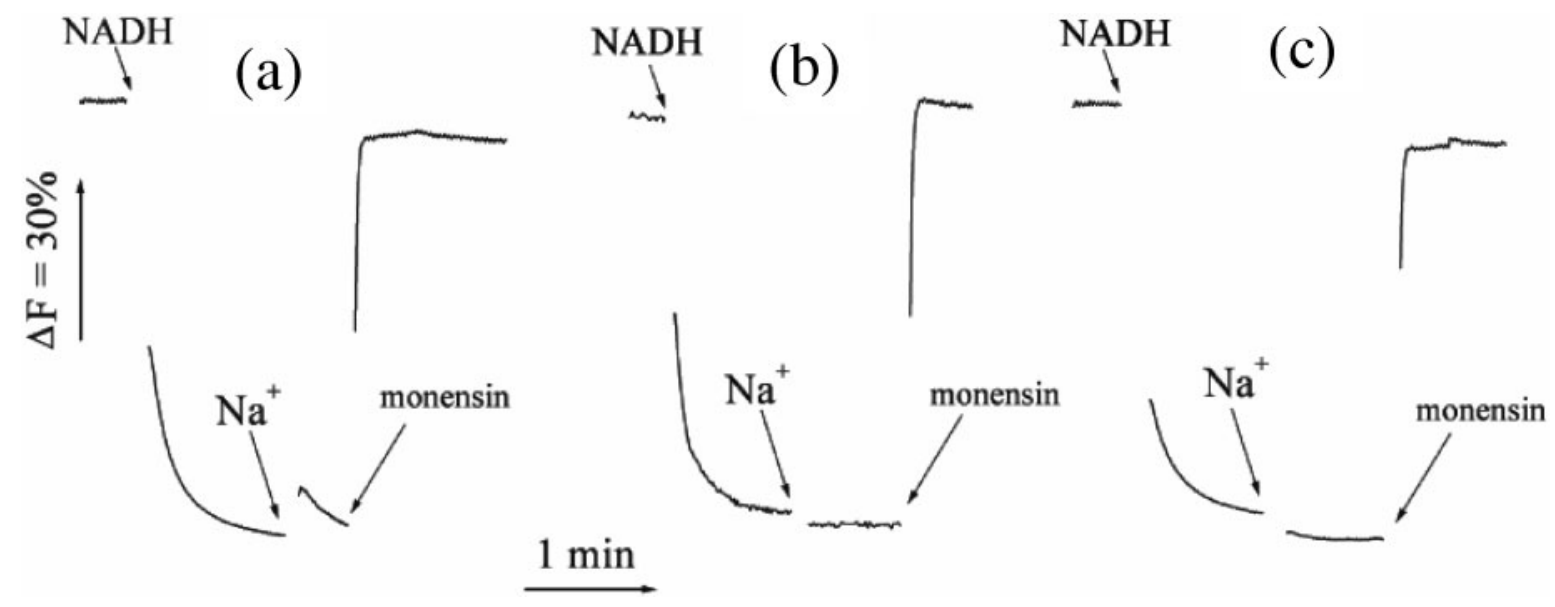

Fig. 3. $\mathrm{Na}^{+} / \mathrm{H}^{+}$-antiporter activity in sub-bacterial particles of $E$. coli GR7ON (a), A. vinelandii AEIV (b) and A. vinelandii GG4 (c). $\Delta \mathrm{pH}$ was monitored with acridine orange in a medium containing $20 \mathrm{mM} \mathrm{HEPES}$-Tris $(\mathrm{pH} 8.0), 5 \mathrm{mM} \mathrm{MgSO}_{4}, 100 \mathrm{mM}$ $\mathrm{KCl}, 4 \mu \mathrm{M}$ acridine orange and sub-bacterial particles $\left(40-60 \mu \mathrm{g}\right.$ protein $\left.\mathrm{ml}^{-1}\right)$. At the onset of the experiment, Tris salt of $\mathrm{NADH}(2 \mathrm{mM})$ was added, and the fluorescence quenching $(\Delta \mathrm{F})$ was recorded. $\mathrm{NaCl}(10 \mathrm{mM})$ was then added, and the new steady state of fluorescence obtained (dequenching) was monitored. When indicated, the artificial $\mathrm{Na}^{+} / \mathrm{H}^{+}$-antiporter monensin $(5 \mu \mathrm{M})$ was added.

alginate production (Núñez et al., 2000a, b; Segura et al., 2003). The current work demonstrates that the absence of $\mathrm{Na}^{+}-\mathrm{NQR}$ enzyme activity also results in increased alginate production. In halophilic bacteria such as Vibrio spp., $\mathrm{Na}^{+}-\mathrm{NQR}$ activity has an important role in both the environmental and pathogenic phases of their life cycle due to their ability to use sodium transmembrane potential for bioenergetic processes (Häse \& Barquera, 2001; Yorimitsu \& Homma, 2001). A. vinelandii is not halophilic; indeed the BS growth medium contains only $2.6 \mathrm{mM} \mathrm{Na}^{+}$and growth is abrogated at concentrations higher than $200 \mathrm{mM}$ $\mathrm{NaCl}$ (data not shown). In a recent study, characterization of the catalytic properties of the A. vinelandii $\mathrm{Na}^{+}-\mathrm{NQR}$ enzyme indicated that the $\mathrm{Na}^{+}-\mathrm{NQR}$ enzyme of $A$. vinelandii possesses the highest affinity for $\mathrm{Na}^{+}$so far described, with an apparent $K_{\mathrm{m}}$ of $0.1 \mathrm{mM}$, an affinity 27 and 6 times higher than those from Vibrio harveyi and Klebsiella pneumoniae, respectively (Fadeeva et al., 2008). This result is consistent with the low concentrations of $\mathrm{Na}^{+}$present in the natural habitat of $A$. vinelandii. In the present work we found that in A. vinelandii the activity of
$\mathrm{Na}^{+} / \mathrm{H}^{+}$-antiporters is either very low or absent in media containing low $\mathrm{Na}^{+}$concentrations $(\sim 2 \mathrm{mM})$. Analysis of the genome sequence of $A$. vinelandii revealed the existence of four genes encoding putative $\mathrm{Na}^{+} / \mathrm{H}^{+}$-antiporters (data not shown). This indicates that, under our tested condition, these genes are not expressed and that the $\mathrm{Na}^{+}-\mathrm{NQR}$ complex is likely to be the main sodium pump. Thus in mutant GG4, which lacks $\mathrm{Na}^{+}-\mathrm{NQR}$, the absence of a transmembrane sodium gradient might be a signal that triggers alginate production (see below). Another possibility is that the lack of the $\mathrm{Na}^{+}-\mathrm{NQR}$ in mutant GG4 decreases the overall $\mathrm{NADH}$ oxidase activity of this bacterium. However, this is unlikely, as the $\mathrm{Na}^{+}-\mathrm{NQR}$ activity in A. vinelandii is very low when compared to that of NDH-2, the main NADH-consuming enzyme of this bacterium (Bertsova et al., 1998). In addition, mutant GG4 is capable of diazotrophic growth at high oxygen concentrations, indicating that this mutant achieves the high respiration rate required for the respiratory protection of the nitrogenase complex (Bertsova et al., 2001).

Table 3. Alginate production by $A$. vinelandii strains in the presence of exogenous $\mathrm{NaCl}$

\begin{tabular}{|c|c|c|c|c|c|}
\hline \multirow{2}{*}{$\begin{array}{l}\text { Added } \mathrm{NaCl} \\
(\mathrm{mM})\end{array}$} & \multicolumn{5}{|c|}{ Alginate production $\left[\mu \mathrm{g}(\mathrm{mg} \text { protein })^{-1}\right]^{\star}$} \\
\hline & AEIV & GG4 (nqrE:: Tn5) & CN14 $\left(n q r E F^{+}\right)$ & ATCC 9046 & ATCN4 (nqrE:: Tn5) \\
\hline 0 & $108 \pm 7$ & $20200 \pm 400$ & $66 \pm 7$ & $1125 \pm 320$ & $12459 \pm 276$ \\
\hline 50 & $37 \pm 3$ & $6270 \pm 540$ & $45 \pm 2$ & $260 \pm 80$ & $6216 \pm 120$ \\
\hline 150 & $2.4 \pm 0.3$ & $1350 \pm 280$ & $3.4 \pm 1$ & $2.9 \pm 0.6$ & $127 \pm 35$ \\
\hline
\end{tabular}

*Alginate was determined in cells grown for $72 \mathrm{~h}$ on solid BS medium (initial $\mathrm{Na}^{+}$concentration $2.6 \mathrm{mM}$ ) in the presence of the indicated concentrations of $\mathrm{NaCl}$. Data shown are the means \pm SD from three replicate cultures. 
The regulation of alginate synthesis by the $\mathrm{Na}^{+}-\mathrm{NQR}$ complex could be similar to the regulation of virulence factors in $V$. cholerae, which are positively controlled by ToxT. TcpP and TcpH are inner-membrane proteins that positively control transcription of toxT. Activation of toxT by $\mathrm{TcpP} / \mathrm{H}$ is reduced at high $\mathrm{NaCl}$ levels and is increased in the absence of $\mathrm{Na}^{+}-\mathrm{NQR}$ complex activity (Häse \& Mekalanos, 1999). As the $\mathrm{Na}^{+}-\mathrm{NQR}$ complex pumps out $\mathrm{Na}^{+}$, it was proposed that $\mathrm{Tcp} P / \mathrm{H}$ might sense elevated extracellular $\mathrm{Na}^{+}$concentrations or some other associated signal to maintain low toxT transcription levels. Alternatively $\mathrm{TcpP} / \mathrm{H}$ might be sensing the level of sodium gradient rather than high $\mathrm{Na}^{+}$concentrations per se (Häse \& Mekalanos, 1999). In this report we have shown that in A. vinelandii alginate production is inhibited by elevated extracellular $\mathrm{Na}^{+}$concentrations; however, our results indicate that this is an effect associated with osmolarity. Further experiments will be necessary to understand the mechanism by which the $\mathrm{Na}^{+}-\mathrm{NQR}$ complex negatively controls alginate production in $A$. vinelandii and whether it involves the participation of elements similar to TcpP and $\mathrm{TcpH}$ of $V$. cholerae or transcriptional regulators, like the sigma factor AlgU and/or the global response regulator GacA, which are essential for alginate production (Castañeda et al., 2000; Martínez-Salazar et al., 1996). On the other hand, we cannot rule out the possibility that the absence of $\mathrm{Na}^{+}-\mathrm{NQR}$ activity leads to a more efficient secretion of alginate, by favouring the activity of the multienzyme complex involved in alginate polymerization, modification and export (Remminghorst \& Rehm, 2006). Collectively our results indicate that in $A$. vinelandii the absence of $\mathrm{Na}^{+}-\mathrm{NQR}$ activity leads to the inability to maintain a transmembrane $\mathrm{Na}^{+}$gradient and to an increase in alginate production.

\section{ACKNOWLEDGEMENTS}

We are grateful to Dr Maddalena V. Coppi and Dr Christopher Wood for critical reading of the manuscript. We thank K. Wilson for kindly providing the miniTn5SSgusA40 transposon, and S. Moreno and Arturo Ocádiz for their technical support. We also thank E. López, P. Gaytán and J. Yañez for the synthesis of primers and DNA sequencing. This research was supported by projects PAPIIT, no. IN214605 and IN214208 from the UNAM. A. V. B. is grateful to the Russian Foundation for Basic Research for financial support (grant 07-04-00619).

\section{REFERENCES}

Alexeyev, M. F., Shokolenko, I. N. \& Croughan, T. P. (1995). New mini-Tn 5 derivatives for insertion mutagenesis and genetic engineering in gram-negative bacteria. Can J Microbiol 41, 1053-1055.

Barquera, B., Hellwig, P., Zhou, W., Morgan, J. E., Häse, C. C., Gosink, K. K., Nilges, M., Bruesehoff, P. J., Roth, A. \& other authors (2002). Purification and characterization of the recombinant $\mathrm{Na}^{+}$. translocating NADH: quinone oxidoreductase from Vibrio cholerae. Biochemistry 41, 3781-3789.

Bertsova, Y. V. \& Bogachev, A. V. (2002). Operation of the $c b b 3$-type terminal oxidase in Azotobacter vinelandii. Biochemistry (Mosc) 67, 622-626.
Bertsova, Y. V. \& Bogachev, A. V. (2004). The origin of the sodiumdependent NADH oxidation by the respiratory chain of Klebsiella pneumoniae. FEBS Lett 563, 207-212.

Bertsova, Y. V., Bogachev, A. V. \& Skulachev, V. P. (1998). Two $\mathrm{NADH}$ : ubiquinone oxidoreductases of Azotobacter vinelandii and their role in the respiratory protection. Biochim Biophys Acta 1363, 125-133.

Bertsova, Y. V., Bogachev, A. V. \& Skulachev, V. P. (2001). Noncoupled NADH:ubiquinone oxidoreductase of Azotobacter vinelandii is required for diazotrophic growth at high oxygen concentrations. J Bacteriol 183, 6869-6874.

Bogachev, A. V., Bertsova, Y. V., Barquera, B. \& Verkhovsky, M. I. (2001). Sodium-dependent steps in the redox reactions of the $\mathrm{Na}^{+}$motive $\mathrm{NADH}$ :quinone oxidoreductase from Vibrio harveyi. Biochemistry 40, 7318-7323.

Bogachev, A. V., Bertsova, Y. V., Ruuge, E. K., Wikstrom, M. \& Verkhovsky, M. I. (2002). Kinetics of the spectral changes during reduction of the $\mathrm{Na}^{+}$-motive $\mathrm{NADH}$ : quinone oxidoreductase from Vibrio harveyi. Biochim Biophys Acta 1556, 113-120.

Campos, M., Martinez-Salazar, J. M., Lloret, L., Moreno, S., Núñez, C., Espin, G. \& Soberon-Chávez, G. (1996). Characterization of the gene coding for GDP-mannose dehydrogenase (algD) from Azotobacter vinelandii. J Bacteriol 178, 1793-1799.

Castañeda, M., Guzmán, J., Moreno, S. \& Espin, G. (2000). The GacS sensor kinase regulates alginate and poly- $\beta$-hydroxybutyrate production in Azotobacter vinelandii. J Bacteriol 182, 2624-2628.

Castañeda, M., Sanchez, J., Moreno, S., Núñez, C. \& Espín, G. (2001). The global regulators GacA and $\sigma^{\mathrm{s}}$ form part of a cascade that controls alginate production in Azotobacter vinelandii. J Bacteriol 183, 6787-6793.

Degli Esposti, M., Ghelli, A., Ratta, M., Cortes, D. \& Estornell, E. (1994). Natural substances (acetogenins) from the family Annonaceae are powerful inhibitors of mitochondrial $\mathrm{NADH}$ dehydrogenase (complex I). Biochem J 301, 161-167.

Dibrov, P., Dibrov, E., Pierce, G. N. \& Galperin, M. Y. (2004). Salt in the wound: a possible role of $\mathrm{Na}^{+}$gradient in chlamydial infection. $J$ Mol Microbiol Biotechnol 8, 1-6.

Dibrov, P., Rimon, A., Dzioba, J., Winogrodzki, A., Shalitin, Y. \& Padan, E. (2005). 2-Aminoperimidine, a specific inhibitor of bacterial $\mathrm{NhaA} \mathrm{Na}{ }^{+} / \mathrm{H}^{+}$antiporters. FEBS Lett 579, 373-378.

Duffy, E. B. \& Barquera, B. (2006). Membrane topology mapping of the $\mathrm{Na}^{+}$-pumping $\mathrm{NADH}:$ quinone oxidoreductase from Vibrio cholerae by PhoA-green fluorescent protein fusion analysis. J Bacteriol 188, 8343-8351.

Fadeeva, M. S., Núñez, C., Bertsova, Y. V., Espín, G. \& Bogachev, A. V. (2008). Catalytic properties of $\mathrm{Na}^{+}$-translocating $\mathrm{NADH}$ : quinone oxidoreductases from Vibrio harveyi, Klebsiella pneumoniae, and Azotobacter vinelandii. FEMS Microbiol Lett 279, 116-123.

Gaona, G., Núñez, C., Goldberg, J. B., Linford, A. S., Nájera, R., Castañeda, M., Guzmán, J., Espín, G. \& Soberón-Chávez, G. (2004). Characterization of the Azotobacter vinelandii algC gene involved in alginate and lipopolysaccharide production. FEMS Microbiol Lett 238, 199-206.

Green, G. N., Kranz, R. G., Lorence, R. M. \& Gennis, R. B. (1984). Identification of subunit I as the cytochrome $b_{558}$ component of the cytochrome $d$ terminal oxidase complex of Escherichia coli. J Biol Chem 259, 7994-7997.

Häse, C. C. \& Barquera, B. (2001). Role of sodium bioenergetics in Vibrio cholerae. Biochim Biophys Acta 1505, 169-178.

Häse, C. C. \& Mekalanos, J. J. (1999). Effects of changes in membrane sodium flux on virulence gene expression in Vibrio cholerae. Proc Natl Acad Sci U S A 96, 3183-3187. 
Häse, C. C., Fedorova, N. D., Galperin, M. Y. \& Dibrov, P. A. (2001). Sodium ion cycle in bacterial pathogens: evidence from cross-genome comparisons. Microbiol Mol Biol Rev 65, 353-370.

Hayashi, M., Hirai, K. \& Unemoto, T. (1995). Sequencing and the alignment of structural genes in the nqr operon encoding the $\mathrm{Na}^{+}-$ translocating $\mathrm{NADH}$-quinone reductase from Vibrio alginolyticus. FEBS Lett 363, 75-77.

Kennedy, C., Gamal, R., Hummprey, R., Ramos, J., Brigle, K. \& Dean, D. (1986). The nifH, nifM, and nifN genes of Azotobacter vinelandii: characterization by Tn 5 mutagenesis and isolation from pLARF1 gene bank. Mol Gen Genet 205, 318-325.

Martínez-Salazar, J. M., Moreno, S., Nájera, R., Boucher, J. C., Espín, G., Soberón-Chávez, G. \& Deretic, V. (1996). Characterization of the genes coding for the putative sigma factor AlgU and its regulators MucA, MucB, MucC, and MucD in Azotobacter vinelandii and evaluation of their roles in alginate biosynthesis. J Bacteriol 178, 1800-1808.

Mejía-Ruiz, H., Guzmán, J., Moreno, S., Soberón-Chávez, G. \& Espin, G. (1997a). The Azotobacter vinelandii alg8 and alg44 genes are essential for alginate synthesis and can be transcribed from an $a \lg D-$ independent promoter. Gene 199, 271-277.

Mejia-Ruiz, H., Moreno, S., Guzmán, J., Nájera, R., León, R., Soberón-Chávez, G. \& Espín, G. (1997b). Isolation and characterization of an Azotobacter vinelandii algK mutant. FEMS Microbiol Lett 156, 101-106.

Miller, J. H. (1972). Experiments in Molecular Genetics. Cold Sping Harbor, NY: Cold Spring Harbor Laboratory.

Nakayama, Y., Hayashi, M. \& Unemoto, T. (1998). Identification of six subunits constituting $\mathrm{Na}^{+}$-translocating $\mathrm{NADH}$ : quinone reductase from the marine Vibrio alginolyticus. FEBS Lett 422, 240-242.

Núñez, C., Moreno, S., Soberón-Chávez, G. \& Espin, G. (1999). The Azotobacter vinelandii response regulator AlgR is essential for cyst formation. J Bacteriol 181, 141-148.

Núñez, C., León, R., Guzmán, J., Espín, G. \& Soberón-Chávez, G. (2000a). Role of Azotobacter vinelandii mucA and mucC gene products in alginate production. J Bacteriol 182, 6550-6556.

Núñez, C., Moreno, S., Cárdenas, L., Soberón-Chávez, G. \& Espín, G. (2000b). Inactivation of the ampDE operon increases transcription of algD and affects morphology and encystment of Azotobacter vinelandii. J Bacteriol 182, 4829-4835.

Padan, E., Venturi, M., Gerchman, Y. \& Dover, N. (2001). $\mathrm{Na}^{+} / \mathrm{H}^{+}$ antiporters. Biochim Biophys Acta 1505, 144-157.
Page, W. J. \& von Tigerstrom, M. (1978). Induction of transformation competence in Azotobacter vinelandii iron-limited cultures. Can J Microbiol 24, 1590-1594.

Rehm, B. H. \& Valla, S. (1997). Bacterial alginates: biosynthesis and applications. Appl Microbiol Biotechnol 48, 281-288.

Remminghorst, U. \& Rehm, B. H. (2006). Bacterial alginates: from biosynthesis to applications. Biotechnol Lett 28, 1701-1712.

Rich, P. R., Meunier, B. \& Ward, F. B. (1995). Predicted structure and possible ionmotive mechanism of the sodium-linked $\mathrm{NADH}$ : ubiquinone oxidoreductase of Vibrio alginolyticus. FEBS Lett 375, 5-10.

Sadoff, H. L. (1975). Encystment and germination in Azotobacter vinelandii. Bacteriol Rev 39, 516-539.

Sambrook, J., Fritsch, E. F. \& Maniatis, T. (1989). Molecular Cloning: A Laboratory Manual, 2nd edn. Cold Spring Harbor, NY: Cold Spring Harbor Laboratory.

Schurr, M. J., Yu, H., Martínez-Salazar, J. M., Boucher, J. C. \& Deretic, V. (1996). Control of AlgU, a member of the $\sigma^{\mathrm{E}}$-like family of stress sigma factors, by the negative regulators MucA and MucB and Pseudomonas aeruginosa conversion to mucoidy in cystic fibrosis. J Bacteriol 178, 4997-5004.

Segura, D. \& Espin, G. (1998). Mutational inactivation of a gene homologous to Escherichia coli pts $P$ affects poly- $\beta$-hydroxybutyrate accumulation and nitrogen fixation in Azotobacter vinelandii. $J$ Bacteriol 180, 4790-4798.

Segura, D., Guzmán, J. \& Espín, G. (2003). Azotobacter vinelandii mutants that overproduce poly- $\beta$-hydroxybutyrate or alginate. Appl Microbiol Biotechnol 63, 159-163.

Skulachev, V. P. (1989). The sodium cycle: a novel type of bacterial energetics. J Bioenerg Biomembr 21, 635-647.

Tokuda, H. \& Unemoto, T. (1982). Characterization of the respiration-dependent $\mathrm{Na}^{+}$pump in the marine bacterium Vibrio alginolyticus. J Biol Chem 257, 10007-10014.

Wilson, K. J., Sessitsch, A., Corbo, J. C., Giller, K. E., Akkermans, A. D. \& Jefferson, R. A. (1995). $\beta$-Glucuronidase (GUS) transposons for ecological and genetic studies of rhizobia and other Gramnegative bacteria. Microbiology 141, 1691-1705.

Yorimitsu, T. \& Homma, M. (2001). $\mathrm{Na}^{+}$-driven flagellar motor of Vibrio. Biochim Biophys Acta 1505, 82-93.

Edited by: M. F. Hynes 